\title{
Tilting at windmills: the law of evocation in geographical indications and designations of origin
}

\begin{abstract}
'Fortune is directing our affairs even better than we could have wished: for you can see over there, good friend Sancho Panza, a place where stand thirty or more monstrous giants with whom I intend to fight a battle and whose lives I intend to take; and with the booty we shall begin to prosper. For this is a just war, and it is a great service to God to wipe such a wicked breed from the face of the earth.'

'What giants?' said Sancho Panza.

'Those giants that you can see over there,' replied his master, 'with long arms: there are giants with arms almost six miles long.'

'Look you here,' Sancho retorted, 'those over there aren't giants, they're windmills, and what look to you like arms are sails - when the wind turns them they make the millstones go round.'

'It is perfectly clear,' replied Don Quixote, 'that you are but a raw novice in this matter of adventures. They are giants; and if you are frightened, you can take yourself away and say your prayers while I engage them in fierce and arduous combat.' ${ }^{1}$
\end{abstract}

The Court of Justice of the European Union recently gave a notable judgment on the concept of evocation in the protection of geographical indications and designations of origin. In response to a reference from Spain's Tribunal Supremo, the opinion of Advocate General Pitruzzella ${ }^{2}$ and the subsequent judgment ${ }^{3}$ of the Fourth Chamber comprise a fascinating deliberation upon the nature of signs and the cultural import of geographical names.

The reference was in relation to a dispute between Industrial Quesera Cuquerella SL ('IQC') and the body administering a Protected Denomination of Origin (PDO), the Fundación Consejo Regulador de la Denominación de Origen Protegida Queso Manchego ('the Foundation'). The dispute arose somewhat poetically in relation to a cultural and commercial intertextuality with Miguel de Cervantes' Don Quixote.

The Foundation administers a PDO, 'Queso Manchego', in relation to cheeses made from sheep's milk in the region of La Mancha. IQC also markets cheeses in the region, although these cheeses are not protected by the PDO. The IQC cheeses are marketed under the name 'Quesos Rocinante' and with a label depicting a knight and a 'bony horse' within a landscape of windmills and sheep. Rocinante is of course the name of Don Quixote's aged horse, 'his nag', who 'had more corns than a barleyfield and more wrong with it than Gonella's horse'. ${ }^{4}$

1. M de Cervantes, Don Quixote, J Rutherford (trans) (Penguin, London 2000/[1604-5/ 1615]) Chapter VIII, 63-4.

2. C-614/17 Queso Manchego v Industrial Quesera Cuquerella SL, Juan Ramón Cuquerella Montagud, EU:C:2019:11 (AGO).

3. C-614/17 Queso Manchego v Industrial Quesera Cuquerella SL, Juan Ramón Cuquerella Montagud, EU:C:2019:344.

4. Cervantes, Don Quixote (n 1) Chapter I, 28. 
The Foundation argued that, given the widely shared cultural significance of Don Quixote, the use of these images and the name evoke the region of La Mancha, the geographical area with which the PDO is associated, and thus the designation itself. Is this 'intertextuality' considerable? Or is it just tilting at windmills? ${ }^{5}$ In his opinion, AG Pitruzzella indeed notes, 'in one of the most famous chapters of Cervantes' novel, Don Quixote fights with windmills, a characteristic element of the La Mancha landscape, which is reproduced on some of the labels used by IQC, as well as on its website'. ${ }^{6}$ In fact, one of the most famous depictions of Don Quixote is regularly cited as Pablo Picasso's 1955 drawing of Don Quixote, a bony Rocinante, Sancho Panza and his donkey, and some windmills. ${ }^{7}$ In tilting at windmills, perhaps 'monstrous giants ${ }^{8}$ are more than imaginary.

That the vehicle for this 'copying' is Don Quixote's horse (and accompanying images) is itself especially intriguing. In naming his horse, Quixote decides after a lengthy deliberation 'to call it Rocinante, that is, Hackafore, a name which, in his opinion, was lofty and sonorous and expressed what the creature had been when it was a humble hack, before it became what it was now - the first and foremost of all the hacks in the world'. ${ }^{9}$ The word Rocin is usually translated as 'nag' or ordinary horse, while its combination with Ante indicates that this was a former state. Rocinante is the horse formerly known as ordinary, as it were.

If evocation is established, from the perspective of the PDO the ordinary is made extraordinary. The question is not whether the consumer is misled about the product, the issue is whether the name and reputation of the PDO is rewritten:

[T] he protection against evocation ... constitutes a kind of sui generis protection, not governed by the criterion of being misleading - which presupposes that the sign that conflicts with the registered name is likely to mislead the public as to the geographical origin or the quality of the product - and not affording protection simply based on the likelihood of confusion. As a result, the main objective of protection against evocation is to protect the traditional quality and reputation of registered names against parasitic acts rather than to protect consumers against misleading conduct. ${ }^{10}$

And indeed, from a socio-cultural perspective, this is where this story of intertextuality becomes even more fascinating. Don Quixote is itself noted for its exploration of the context for reading, the circumstances for understanding, indeed, that 'decisive criterion' of 'the consumer's perception' and the 'association of ideas'. ${ }^{11}$ In many respects it is itself a novel on the nature of evocation, where characters are also readers, a history of fiction, an imaginary of fact, an intertextuality of forms: 'Cervantes

5. 'To tilt at windmills' is an idiom derived from the story of Don Quixote, meaning to fight imaginary foes or adversaries.

6. C-614/17 Queso Manchego v Industrial Quesera Cuquerella SL, Juan Ramón Cuquerella Montagud, EU:C:2019:11 (AGO): para 8.

7. The image is descripted as 'the most reproduced graphic version of MC's character of all time and ranks second only to the works of Doré in shaping the popular conception of DQ', H Mancing, The Cervantes Encyclopedia: Volume II, L-Z (Greenwood Press, Westport CT 2004): 'Pablo Picasso'.

8. Cervantes, Don Quixote (n 1) Chapter VIII, 63.

9. Cervantes, Don Quixote (n 1) Chapter I, 28.

10. C-614/17 Queso Manchego v Industrial Quesera Cuquerella SL, Juan Ramón Cuquerella Montagud, EU:C:2019:11 (AGO): para 17.

11. Ibid para 24. 
takes pleasure in confusing the objective and the subjective, the world of the reader and the world of the book'. ${ }^{12}$

In determining evocation, consumer perception is, as mentioned above, 'the decisive criterion'. ${ }^{13}$ The consumer is reader. Evocation is a matter of interpretation, the interpretation on the part of the consumer, 'reasonably well informed and reasonably observant and circumspect'. ${ }^{14}$ What is at stake is signification:

An image, a symbol and, more generally, a figurative sign can, like a name, convey a concept and therefore be capable of triggering in the consumer a mental association with the protected name, which in this case will be 'evoked', not visually or phonetically, but by reference to its conceptual content. ${ }^{15}$

Evocation thus 'brings to mind' the relationship between original and copy, the nature or otherwise of imitation, and the way in which this kind of associative imaginary can convey the extraordinary for the ordinary. Without any reference to substance, without any attempt to copy the name, the form or signifier, the association is nevertheless made. It is in what is signified, the concept itself, that the 'copying' is found. The concept that attends to the signifier (the name, Rocinante, the drawings of Don Quixote and the bony horse, windmills and so on) is one that has been created by the consumers themselves, as it were. It is arbitrary; ${ }^{16}$ it is social. ${ }^{17}$

These qualities of reading and interpretation, and the circumstances for that reading, are explored in a startling little story on the authorship of Don Quixote itself, the very reputation of the name, the legacy of the story, and the interruption of the reader. Written in 1939 by Jorge Luis Borges, 'Pierre Menard, author of the Quixote' tells the story of Pierre Menard who, in an effort of independent creation, endeavours to write a story apparently identical to Miguel de Cervantes' Don Quixote:

He did not want to compose another Don Quixote - which would be easy - but the Don Quixote. It is unnecessary to add that his aim was never to produce a mechanical transcription of the original; he did not propose to copy it. His admirable ambition was to produce pages which would coincide - word for word and line for line - with those of Miguel de Cervantes. ${ }^{18}$

This story is itself famous, 'undoubtedly one of Borges' most famous and critically elaborated texts' ${ }^{19}$ It is frequently cited as a commentary on imitation and 'the death of the author', and

Menard (perhaps without wishing to) has enriched, by means of a new technique, the hesitant and rudimentary art of reading: the technique is one of deliberate anachronism and erroneous

12. JL Borges, 'Partial Magic in the Quixote', in Labyrinths: Selected Stories \& Other Writings, DA Yates and JE Irby (eds), JE Irby (trans) (New Directions, New York 1962) 193-6, 194.

13. C-614/17 Queso Manchego v Industrial Quesera Cuquerella SL, Juan Ramón Cuquerella Montagud, EU:C:2019:11 (AGO): para 24.

14. Ibid para 53 .

15. Ibid para 25 .

16. F de Saussure, Course in General Linguistics, W Baskin (trans) (Philosophical Library, New York 1959): 'The bond between the signifier and the signified is arbitrary' (p. 67).

17. CS Peirce, Collected Papers: Volume 2 Elements of Logic, C Hartshorne and P Weiss (eds) (Harvard UP, Cambridge MA 1932): 'Nothing is a sign unless it is interpreted as a sign' (p. 172). 18. JL Borges, Ficciones, A Kerrigan (ed), A Bonner (trans) (Grove Press, New York 1962/ [1956]) 45-55, 48-9.

19. R Butler, Borges' Short Stories (Continuum, London 2010) 46. 
attributions. This technique, with its infinite applications, urges us to run through the Odyssey as if it were written after the Aeneid. ${ }^{20}$

In other words, it is not so much about the origins of the story, but about how what follows creates and interprets the original. Curiously, the original comes about because of the 'copy'. The sign is arbitrary, so how can we be certain what imitation is, if Menard makes Cervantes? This investment of interpretation may seem to transform and unhinge the work, but only 'almost', as it were: 'On the contrary, the page that becomes immortal can traverse the fire of typographical errors, approximate translations, and inattentive or erroneous readings without losing its soul in the process. ${ }^{21}$ Thus, rather than an endorsement of a banal relativism, the story articulates the relationships between works, the intertextuality, the social production of meaning. This resonates with the present dispute; it is precisely through the challenge and interpretation of IQC's marketing, that a new version of the PDO name, Queso Manchego, comes to be understood. Evocation is both constituted by and constitutive of the registered name's concept.

Just as Menard's wondrous interpretation remakes Don Quixote, Queso Rocinante has in some respects redefined the original PDO and what it is saying. The concept of evocation imports into the law an accounting for this very process of interpretation and re-reading.

Indeed, the uneasy relationship with imitation circulates throughout intellectual property and the endorsement of the original. For example, a counterfeit is ordinarily understood to be a kind of literal copy, 'word for word and line for line', just like Pierre Menard's Don Quixote. It is certainly not a question of evocation, but in some respects the critical principles underpinning evocation are informative here. Consider the example of a counterfeit handbag. The nature of its interpretation on the part of the consumer suggests a similar kind of process. There are of course exceptions, but in most cases, the circumstances of the act of purchasing the counterfeit leave little room for doubt as to the authenticity of the bag (the location, price, and other elements of the context for consumption). It is thus not always about consumer protection, about whether consumers are misled or deceived. In these kinds of conditions, the counterfeit might even be said to endorse the original and to a large extent does not replace the original. Instead, the issue is one of protecting the reputation and name. Although this example might seem quite different from the nature of evocation in geographical indications (the dispute concerns a product, and the bag and associated trade marks are explicitly copied), the damage is in terms of the associative concepts, the consumer's perception, and the reputation of the name. As in Menard's Don Quixote, we may see an exact transcription of the words of Cervantes, but we interpret something completely different. In that sense, at least in its relationship with the purchaser, the counterfeit bag is not a copy: 'The text of Cervantes and that of Menard are verbally identical, but the second is almost infinitely richer. (More ambiguous, his detractors will say; but ambiguity is a richness.)' 22 The circumstances of buying, the circumstances of reading (for example, centuries apart), inform the process of interpretation and perception. Quoting identical passages from each book, Borges notes: 'Equally vivid is the contrast in styles. The archaic style of Menard - in the last analysis, a foreigner - suffers from a certain affectation. Not so that of his precursor, who

20. JL Borges, Ficciones (n 18) 54-5.

21. JL Borges, 'The Superstitious Ethics of the Reader', in The Total Library: Non-Fiction 1922-1986, E Weinberger (ed), SJ Levine (trans) (Penguin, London 1999) 52-5, 54.

22. JL Borges, Ficciones (n 18) 52. 
handles easily the ordinary Spanish of his time. ${ }^{23}$ The same words from Menard in the early twentieth century come to mean something quite different from those of Cervantes, the 'ingenious layman', ${ }^{24}$ writing in the seventeenth. And at the same time, the 'foreigner' reaffirms the 'precursor' as origin.

Thus, a consideration of the concept of evocation in the law of geographical indications is not simply about the potential for figurative signs to conjure associations with geographic regions, or even to evoke registered names. It is also about how 'the average consumer' comes to reinscribe the origin of the name. The windmill, the imaginary foe, is the notion of consumer deception. But perhaps the monstrous giants are the signs themselves, with their 'arms almost six miles long' embracing a wider terrain.

In the process of evocation, the law moves from signifiers to signified. And indeed in the articulation of geographical indications, the consumer is prepared to do the same:

Indeed, it is the direction of meaning which determines the two major management functions of the classic text: the author is always supposed to go from signified to signifier, from content to form, from idea to text, from passion to expression; and, in contrast, the critic goes in the other direction, works back from signifiers to signified. ${ }^{25}$

The protection through evocation is not that of a product, but of an identity and a social and collaborative production of meaning:

[P]erhaps the emphasis on the product itself is also only a matter of perspective, as it were. Arguably, the GI protects less a 'product' as such, but rather the identity or process or 'sensation' of that product. In many ways, it is the relationship between the product and the social place (that is, the people together with the social and creative meaning of place) that is important. $^{26}$

In some ways, this episode is a parable for how we read and imitate through reading, how we create through reading, how audiences matter. Just like the windmills, the social life of PDOs are like 'affairs of war', and 'ever more than others, are subject to continual change' ${ }^{27}$

As Sancho Panza would say, 'And only someone with windmills on the brain could have failed to see that!'28

Johanna Gibson

April 2019

23. Ibid 53 .

24. Ibid 53 .

25. R Barthes, S/Z, R Miller (trans) (Blackwell, Malden MA 1974/[1973]) 174 (original emphasis).

26. J Gibson, 'Geographies of Taste, Fashion, Tradition and Place', in G Ghidini, H Ullrich and P Drahos (eds), Kritika: Essays on Intellectual Property. Volume 2 (Edward Elgar, Cheltenham 2017) 140.

27. Cervantes, Don Quixote (n 1) Chapter VIII, 64.

28. Ibid 64 . 